\title{
A 10-year study of background surface ozone concentrations on the island of Gozo in the Central Mediterranean
}

\author{
Martin Saliba • Raymond Ellul • Liberato Camilleri • \\ Hans Güsten
}

Received: 14 March 2008 / Accepted: 8 October 2008 / Published online: 23 October 2008

(C) Springer Science + Business Media B.V. 2008

\begin{abstract}
A 10-year study of surface ozone mixing ratios in the Central Mediterranean was conducted based on continuous ozone measurements from 1997 to 2006 by a background regional Global Atmospheric Watch (GAW) station on the island of Gozo. The mean annual maximum mixing ratio is of the order of $66 \mathrm{ppbv}$ in April-May with a broad secondary maximum of $64 \mathrm{ppbv}$ in July-September. No long-term increase or decrease in the background level of surface ozone could be observed over the last 10 years. This is contrary to observations made in the Eastern Mediterranean, where a slow decrease in the background ozone mixing ratio was observed over the past 7 years. Despite the very high average annual ozone mixing ratio exceeding $50 \mathrm{ppbv}$ - in fact, the highest average background ozone mixing ratio ever measured in Europe-, the diurnal $\mathrm{O}_{3}$ max $/ \mathrm{O}_{3}$ min index of $<1.40$ indicates that the island of Gozo is a good site for measuring background surface ozone. However, frequent photosmog events from June to September during the past 10 years with ozone mixing ratios exceeding $90 \mathrm{ppbv}$ indicate that the Central Mediterranean is prone to long-range transport of air pollutants from Europe by northerly winds. This was particularly evident during the so-called "August heatwave" of the year 2003 when the overall ozone mixing ratio was 4.6 ppbv higher than the average of all other 9 months of August since 1997. Air mass back-trajectory analysis of the August 2003 photosmog episodes on Gozo confirmed that ozone pollution originated from the European continent. Regression analysis was used to analyse the 10 -year data set in order to model the behaviour of the ozone mixing ratio in terms of the meteorological parameters of wind speed, relative humidity, global radiation, temperature, month of year, wind sector,
\end{abstract}

M. Saliba $\cdot$ R. Ellul $(\triangle)$

Department of Physics, University of Malta, Msida MSD 2080, Malta

e-mail: ray.ellul@um.edu.mt

L. Camilleri

Department of Statistics and Operations Research, University of Malta, Msida MSD 2080, Malta

H. Güsten

Institut für Meteorologie und Klimaforschung, Forschungszentrum Karlsruhe/Universität Karlsruhe, 76021 Karlsruhe, Germany 
atmospheric pressure, and time of day (predictors). Most of these predictors were found to significantly affect the ozone mixing ratios. From March to November, the monthly average of the AOT40 threshold value for the protection of crops and vegetation against ozone was constantly exceeded on Gozo during the past 10 years.

Keywords Ozone $\cdot$ Mediterranean $\cdot$ Gozo $\cdot$ Long-range transport · Forecast ·

Statistical model $\cdot$ AOT40 value

\section{Introduction}

Ozone has been well-established as a natural greenhouse gas and also as an air pollutant with a clear impact on humans, crops, and vegetation. As a natural trace gas, it is transported from the stratosphere in the tropics and extratropics into the free troposphere. As an air pollutant, ozone is generally produced by photochemical reactions from precursor molecules in the boundary layer (Güsten 1986; Altshuller and Bufalini 1972). Detailed knowledge of its photochemical production, trends, and control is therefore required (Güsten 1986).

The global background ozone mixing ratio over the last few decades was reviewed recently by Vingarzan (2004). Jonson et al. (2006) reported the trends of European ozone levels.

The annual cycle of ozone at background sites in the Northern hemisphere is clearly characterised by a spring maximum which may be broadened by local ozone production during the summer. The spring maximum may originate from both enhanced photochemistry in the free troposphere as well as from stratospheric-tropospheric exchanges (Vingarzan 2004; Monks 2000).

Modern-day annual average background ozone mixing ratios over the midlatitudes of the Northern hemisphere are in the range of approximately $20-45 \mathrm{ppbv}$, with the variability being a function of geographic location, elevation, and the extent of anthropogenic influence (Scheel et al. 1997).

Background ozone levels continued to rise over the last three decades by about $0.5-2.0 \%$ per annum. Relatively steep trends in the 1970s and 1980s gave way to more modest increases in the 1990s when mitigating measures started to become effective (Vingarzan 2004).

Transatlantic transport of North American air pollution affects Europe (Lelieveld et al. 2002).

According to IPCC scenarios, the average global surface ozone mixing ratio is expected to increase from the present $20-45$ to $42-84$ ppbv by 2100 . Such an increase would be very detrimental to human health, crops, and vegetation (Vingarzan 2004; Nakicenovic et al. 2000; WHO 1987).

Jonson et al. (2006) discuss a number of factors which affect near-surface ozone levels over Europe and attempt, with partial success only, to account for the observed trends in terms of European emissions of ozone precursors.

In the Mediterranean, the background surface ozone mixing ratios are the highest in Europe (Kouvarakis et al. 2000, 2002; Gerasopoulos et al. 2005; Nolle et al. 2002; Lelieveld et al. 2002). According to Nolle et al. (2005), the ozone mixing ratio in the Central Mediterranean might have increased by a factor of five over the last century.

Here, it will be reported about the variation of background surface ozone levels since the beginning of a Maltese-German research project which started measuring ozone levels in 1997 and is continued until the present day. 


\section{Experimental methods and data evaluation}

The experimental set-up at the GAW Giordan lighthouse station was described in detail in an earlier publication (Nolle et al. 2002). Over the years, this set-up has been improved and a second ozone analyser was added in early 2005 to substantiate and back-up the first ozone analyser at the lighthouse. This second analyser is a Dasibi model $1008 \mathrm{AH}$. Calibration was performed against the secondary standard ozone monitor used at our main laboratory in Xewkija (Environnement model $\mathrm{O}_{3} 41 \mathrm{M}$ ). The ozone instruments were calibrated using a portable ozone transfer standard (Model O3, UMEG, Karlsruhe) from the institute in Karlsruhe, which itself was checked against an absolute long-path optical cell (Model R-UV-PH, UMEG, Karlsruhe).

Since 2003, an $\mathrm{SO}_{2}$ monitor (Monitor Labs, ML9850) has been installed at the lighthouse and it, together with the Horiba CO monitor installed in 1999, allowed for an identification of emissions of more regional origin. The $\mathrm{CO}$ monitor was modified according to Dickerson and Delany (1988) in order to minimise the cross sensitivity of water vapour. The detection limit of the modified $\mathrm{CO}$ analyser is $20 \mathrm{ppbv}$ and that of the $\mathrm{SO}_{2}$ analyser is $0.5 \mathrm{ppbv}$. Use of the HYSPLIT-4 back trajectory model (HYSPLIT-4, 1997) allowed for an identification of possible sources of anthropogenic emissions in the Central Mediterranean.

The coordinates of the lighthouse are $36^{\circ} 4^{\prime} 24^{\prime \prime}$ north; $14^{\circ} 13^{\prime} 9^{\prime \prime}$ east (Fig. 1). Trace gas measurements are made with the air intakes at a height of $167 \mathrm{~m}$ above sea level;

Fig. 1 Classification of wind sectors for air masses arriving at the Giordan lighthouse station and average wind rose on Gozo for the years 1997-2006. The Maltese islands are shown on the inset of the map of the Mediterranean and surrounding countries. The wind sectors are numbered 1 to 6. Sector 3 indicates polluted wind from the main island

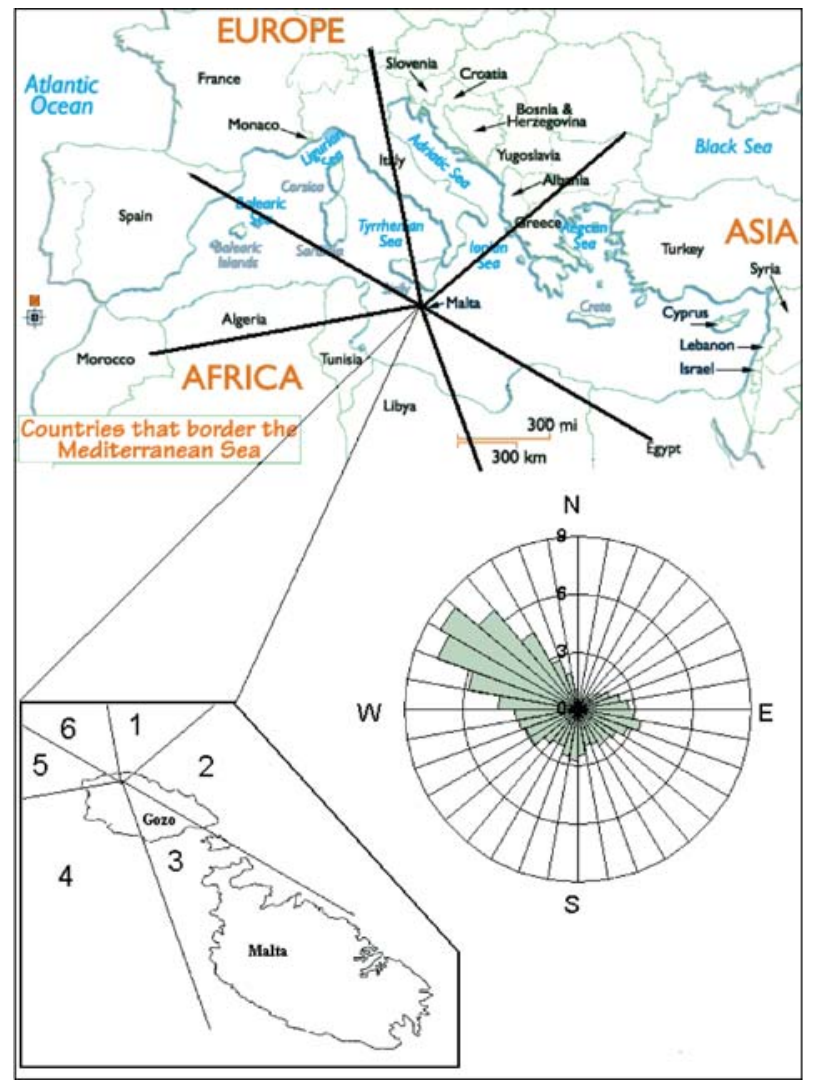


the anemometer is installed at the highest point of the lighthouse at $181 \mathrm{~m}$ above sea level.

Data are collected every $10 \mathrm{~s}$ by all instruments, including the meteorological parameters of wind speed and direction, relative humidity, and temperature. These parameters are also measured at the Xewkija station where, in addition, the pressure and global radiation are determined using a calibrated Vaisala PTB 101 B barometric pressure sensor and a Kipp and Zonen SP-Lite pyranometer. For all intents and purposes, the pressure and global radiation measurements at Xewkija are assumed to be valid for the lighthouse which is only $6 \mathrm{~km}$ away.

Since not all meteorological parameters were measured in the early days of the project, these gaps in the data set were closed by local meteorological data from the meteorological office at Malta International Airport and global radiation measurements by the Institute of Energy Technology of the University of Malta. These are located approximately 20 and $30 \mathrm{~km}$ south-east of Giordan lighthouse, respectively, on the main island of Malta. Again, the data were assumed to be valid for the lighthouse site after correction for altitude in the case of the pressure sensor.

All data collected are averaged every $15 \mathrm{~min}$ and for the purpose of this work, these data are averaged again to hourly values in order to realistically cope with the large amount of data accumulated over 10 years.

The relationship between the ozone mixing ratio and the meteorological parameters that influence local ozone mixing ratios is studied using regression analysis with the help of an SPSS statistical package (Statistics Package for Social Sciences, SPSS Inc., 233 South Wacker Drive, 11th Floor, Chicago, Il 60606-6412, USA. See also website: http://www. spss.com/worldwide).

\section{Results and discussion}

\subsection{Meteorology of the Maltese islands}

The detailed meteorology of the Maltese islands has been reviewed by Chetcuti et al. (1992). Own measurements of wind speed and direction, temperature, relative humidity, and global radiation, with the gaps filled by the above-mentioned data sets for all 10 years reveal the consequence; emissions are picked up from this island which is heavily populated (pop. 400,000) with approximately 250,000 vehicles as well as light industry.

The predominant wind direction (Fig. 1) is from the northwest with a strong component from the east and smaller contributions from the southeast and other directions. It is interesting to note that the windrose for Gozo measured more than a century ago has not changed over this long time span (Nolle et al. 2005). When the wind blows from the SE in the sector $120^{\circ}-140^{\circ}$, it is effectively blowing over the main island of Malta. The monthly averages of the temperature for all 10 years shows a clear maximum in August (highest mean value: $28^{\circ} \mathrm{C}$ ) and a minimum in February (lowest mean value: $10^{\circ} \mathrm{C}$ ). The year 2003 stands out somewhat as the summer heat lasted longer and was more pronounced than in the other 9 years.

The monthly averages of the relative humidity over the past 10 years are always high and range between $72-79 \%$ for all seasons with small maxima in spring and autumn.

The global radiation daily mean values for all 10 years vary between 347 and $384 \mathrm{Wm}^{-2}$. Solar radiation in the hot year 2003 was not exceptionally high, the annual mean value reached $380 \mathrm{Wm}^{-2}$. As expected, the variation of global radiation with the months of the year reaches a maximum in May-August for all years. 


\subsection{Trends in surface ozone levels on Gozo}

A clear diurnal cycle of the ozone mixing ratio is observed (not shown). All 10 years conform to this previously described behaviour (Nolle et al. 2002), with the maximum and minimum of the diurnal cycle varying with the time of day between winter and summer. For further discussion, reference is made to Nolle et al. 2002.

The hourly ozone mean observations over the past 10 years (1997-2006) are summarised by monthly averages and shown in a histogram in Fig. 2a. Figure $2 b$ shows the seasonal cycle of monthly averages of the ozone mixing ratios over 10 years, indicating clearly the spring ozone maximum in April-May with a strong shoulder over the summer months lasting to September.

The annual averages of the ozone mixing ratios for all 10 years are shown in Fig. 2c. Outstanding is the year 2003, with a mean of 56.6 ppbv being reached.

For a trend analysis of this long-term ozone data set, two approaches are adopted.

The first approach computes the percentiles for each individual year. These ozone mixing ratio percentiles are then combined in one data set and a linear regression analysis is performed for each percentile with the year taken as parameter. The variations of the ozone mixing ratio percentiles, together with the linear regression (represented by a trend line), are shown in Fig. 3. The 100th percentile (maximum ozone mixing ratio) decreases at an annual rate of $1.1 \mathrm{ppbv}$, while the median (50th percentile) increases by $0.2 \mathrm{ppbv}$ and the 0th percentile (minimum ozone mixing ratio) decreases by $0.1 \mathrm{ppbv}$ per annum; this latter value is not considered to be significant.

The second approach (see also section 3.5) involved the use of regression modelling to plot the daily maximum and minimum mean values of the ozone mixing ratio for all 10 years and to examine the differences in the slopes of the "maxima" and "minima" (Fig. 4a,b).

Since 2003 was a special year with mean ozone mixing ratios higher than expected (see Fig. 2c), the gradients are computed both with and without this year.

The findings are as follows:

The regression model for maximum ozone, including the year 2003, indicates that the maximum ozone mixing ratio increases by $0.10 \mathrm{ppbv}$ per annum on the average. This rate is not significantly different from zero. The regression model for maximum ozone, excluding the year 2003, indicates that the maximum ozone mixing ratio decreases by $0.01 \mathrm{ppbv}$ per annum on the average. This rate is also not significantly different from zero.

Both calculations therefore confirm that the maximum ozone mixing ratio did not increase over the past 10 years.

The regression model for minimum ozone, including the year 2003, indicates that the minimum ozone mixing ratio increases by $0.22 \mathrm{ppbv}$ per annum on the average. This rate is statistically not different from zero.

The regression model for minimum ozone, excluding 2003, indicates that the minimum ozone mixing ratio increases by 0.15 ppbv per annum on the average. This rate is also statistically not different from zero.

It is therefore concluded that the maximum ozone mixing ratio as well as the minimum ozone mixing ratio were constant over the past 10 years.

The results for Gozo are in contrast to the results of Gerasopoulos et al. (2005), who found a significant annual decrease in the ozone mixing ratio of $1.64 \mathrm{ppbv}$ for the Eastern Mediterranean for a 7-year period from 1997 to 2004.

It was proposed that the daily $\mathrm{O}_{3} \max / \mathrm{O}_{3}$ min ratio is a pollution indicator (Cvitas and Klasinc 1993; Beck and Grennfelt 1993). For urban sites pollution index values in excess of 


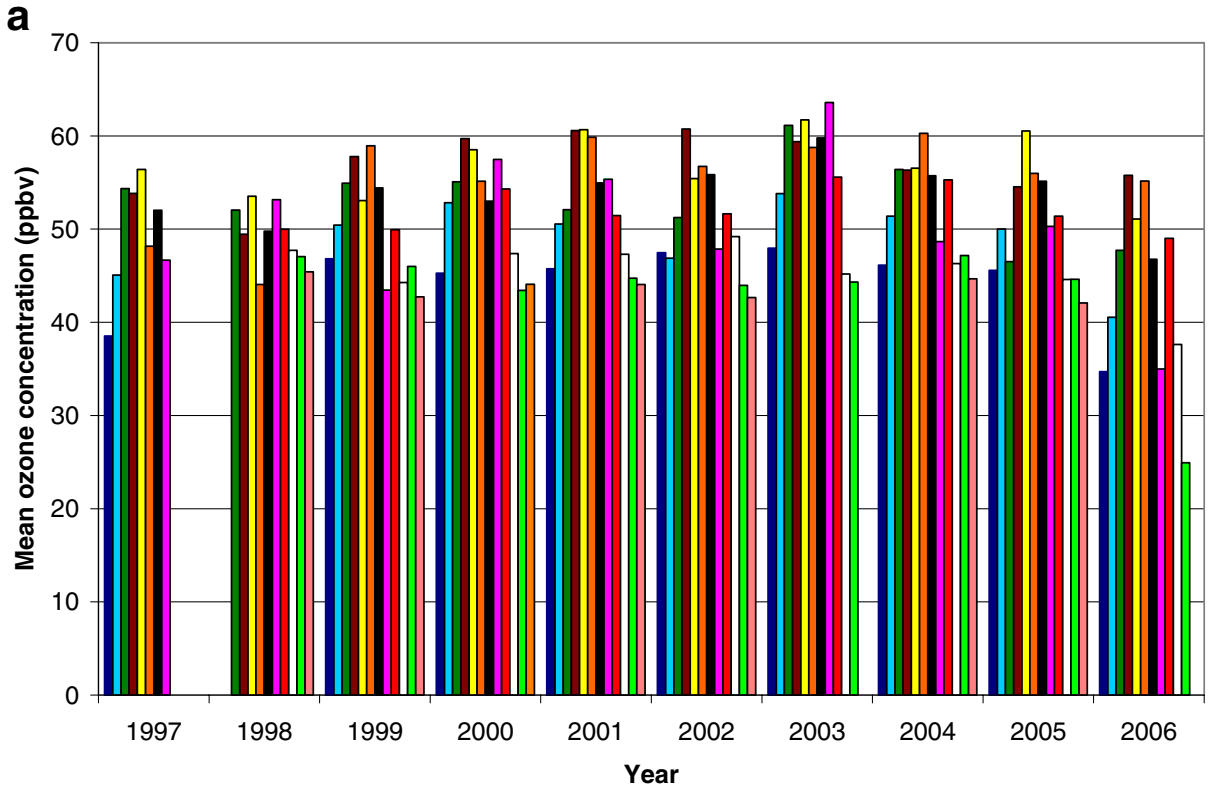

-Jan $\square$ Feb $\square$ Mar $\square$ Apr $\square$ May $\square$ Jun $\square$ Jul $\square$ Aug $\square$ Sep $\square$ Oct $\square$ Nov $\square$ Dec

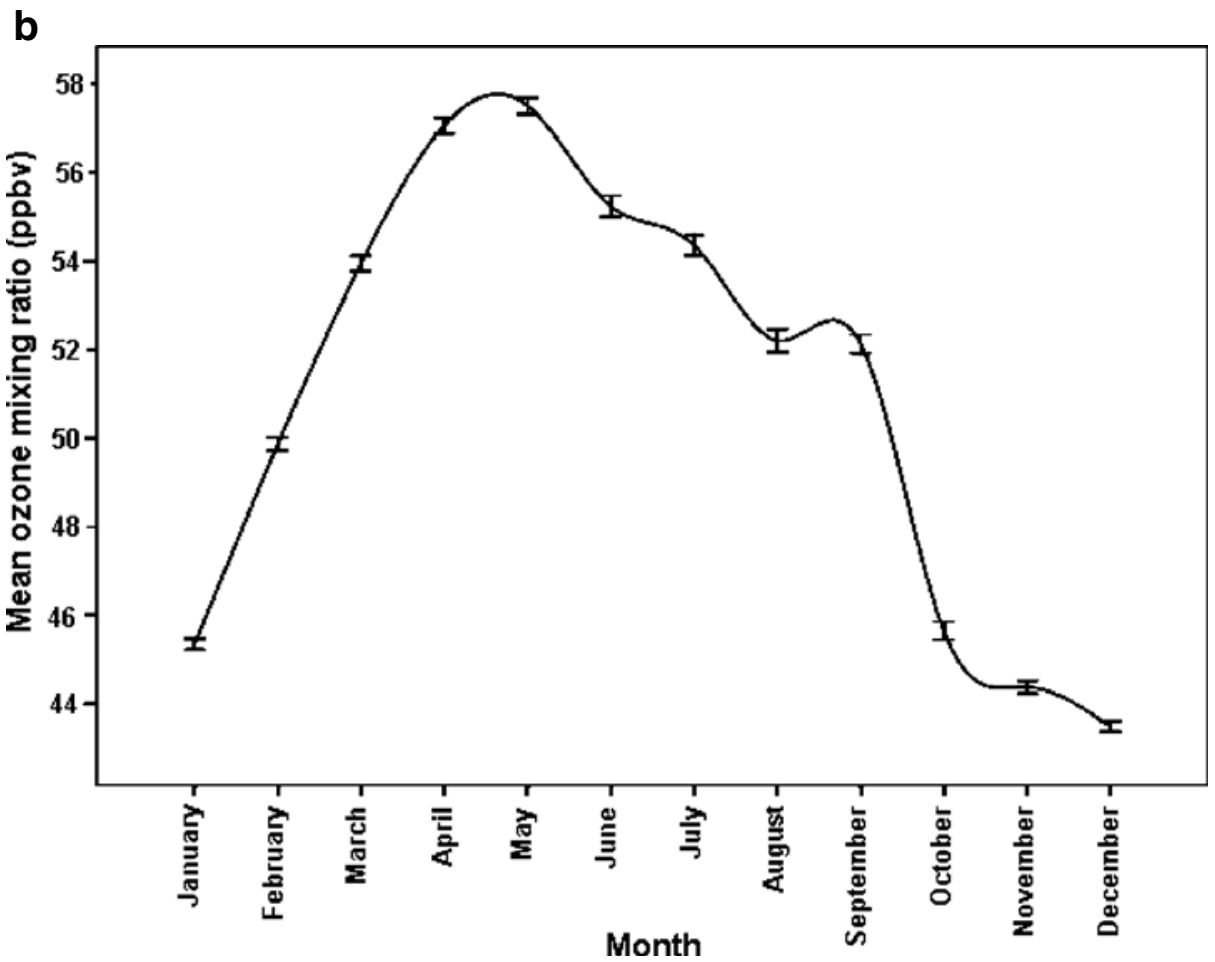

Fig. 2 a Annual average of the ozone mixing ratio for the years 1997-2006 on the island of Gozo. b Combined monthly average of the ozone mixing ratios from January 1997 to December 2006 on Gozo. c Annual averages of ozone mixing ratios from January 1997 to December 2006 on Gozo 


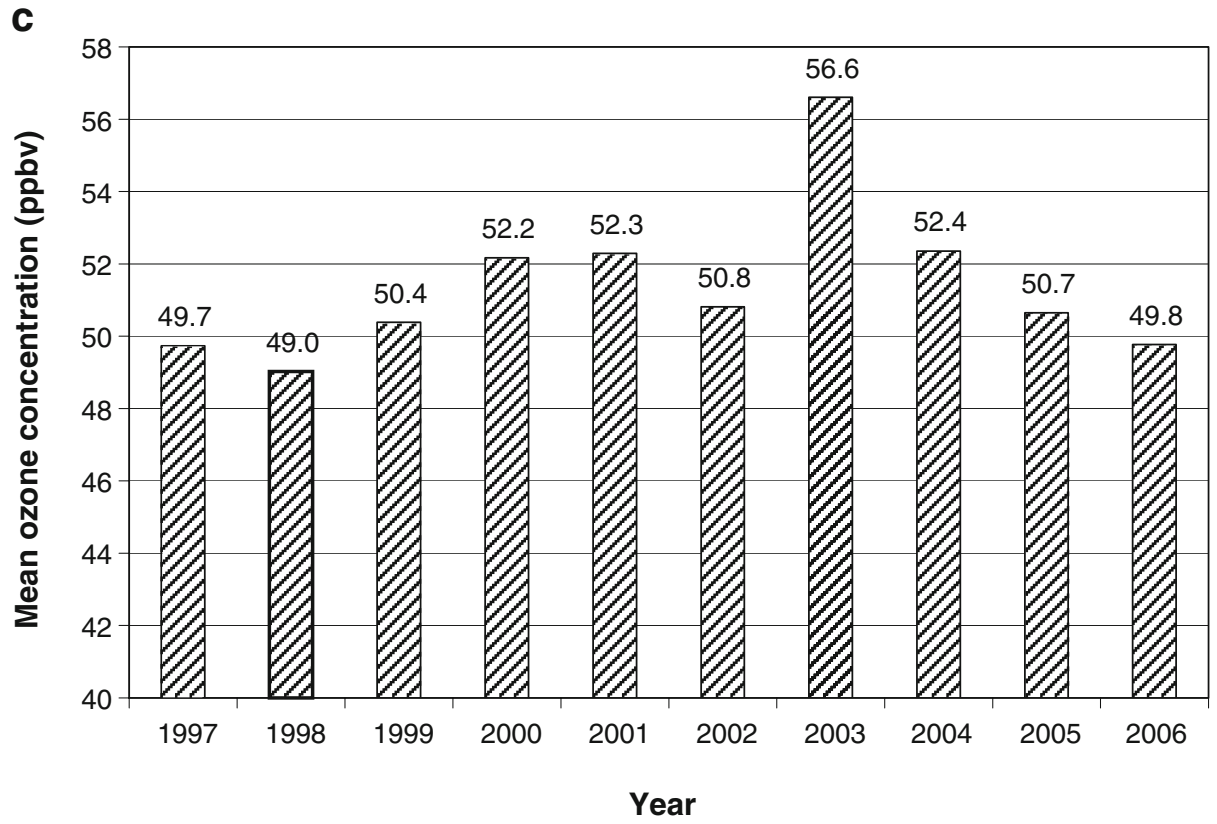

Fig. 2 (continued)

10 are reported (Cvitas et al. 1995, 1997), whereas low values smaller than 1.4 indicate a site with the ozone background mixing ratios being uncontaminated by local ozone formation or transport phenomena (Scheel et al. 1997). From all monthly maximum and minimum ozone mixing ratios over the last 10 years (data from 115 months), the annual maximum and minimum ozone concentrations are derived and compiled in Table 1.

Despite the high annual mean ozone mixing ratios on Gozo (see Fig. 2c), the pollution index for all 10 years is equal to or less than 1.40 . The same pollution index value is reached at Mace Head $\left(53.3^{\circ} \mathrm{N}, 9.9^{\circ} \mathrm{E}\right)$, a very remote measuring site on the West coast of Ireland. Contrary to Mace Head which may be considered representative of the European boundary layer ozone background mixing ratio (Beck and Grennfelt 1993), the high average annual ozone mixing ratio on Gozo, i.e. the large difference between the annual means of 34 ppbv ozone at Mace Head and a value in excess of 50 ppbv on Gozo, remains to be explained.

The question arises whether the measuring station at Giordan lighthouse measures background surface ozone. The lighthouse stands $800 \mathrm{~m}$ away from the northwestern coast on a cliff facing the sea and the strait between Gozo and Sicily; at first sight, an ideal location for a clean air and background surface ozone station. Furthermore, Gozo is a small island (about $67 \mathrm{~km}^{2}$ ) with a more or less maritime boundary layer (see Fig. 1). Thus, nighttime ozone removal due to vertical exchange, night-time chemistry, and dry deposition are reduced as compared to continental measuring sites. A comparison with long-term ozone measurements over Europe (Scheel et al. 1997), however, indicates that the average annual surface ozone mixing ratios on Gozo are the highest in Europe. None of the annual mean ozone concentrations measured at 25 measuring sites in Europe from $28.3^{\circ}$ north to $78.9^{\circ}$ north exceeded 50 ppbv. 


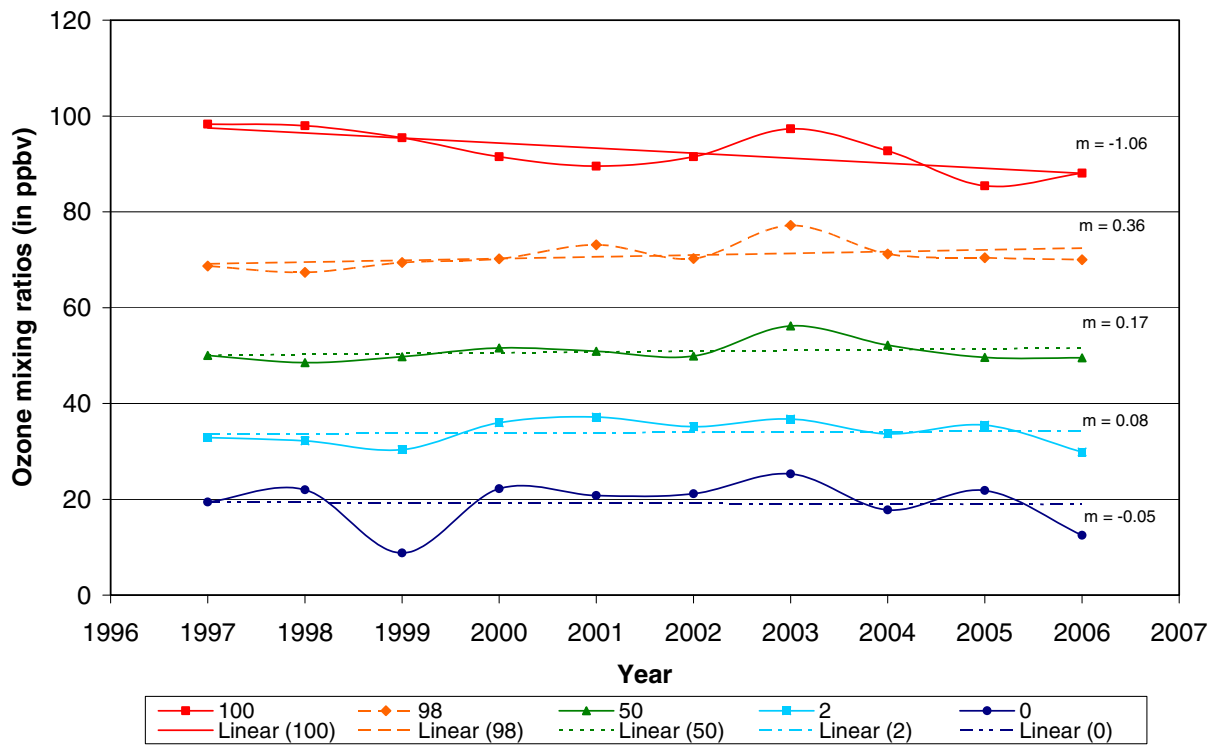

(gradient $\mathrm{m}=$ growth rate)

Fig. 3 Percentiles of the ozone mixing ratio from January 1997 to December 2006 on Gozo

High ozone mixing ratios exceeding 90 ppbv (threshold value for public notification) were often recorded at Giordan lighthouse. When compiling a list of events of such high ozone mixing ratios measured on Gozo over the last 10 years, 20 episodes are obtained with all but two of them occurring in the summer months.

The local timing of the events, sometimes during the night, as well as the wind direction coupled with back trajectory calculations indicate that the high ozone mixing ratios are not

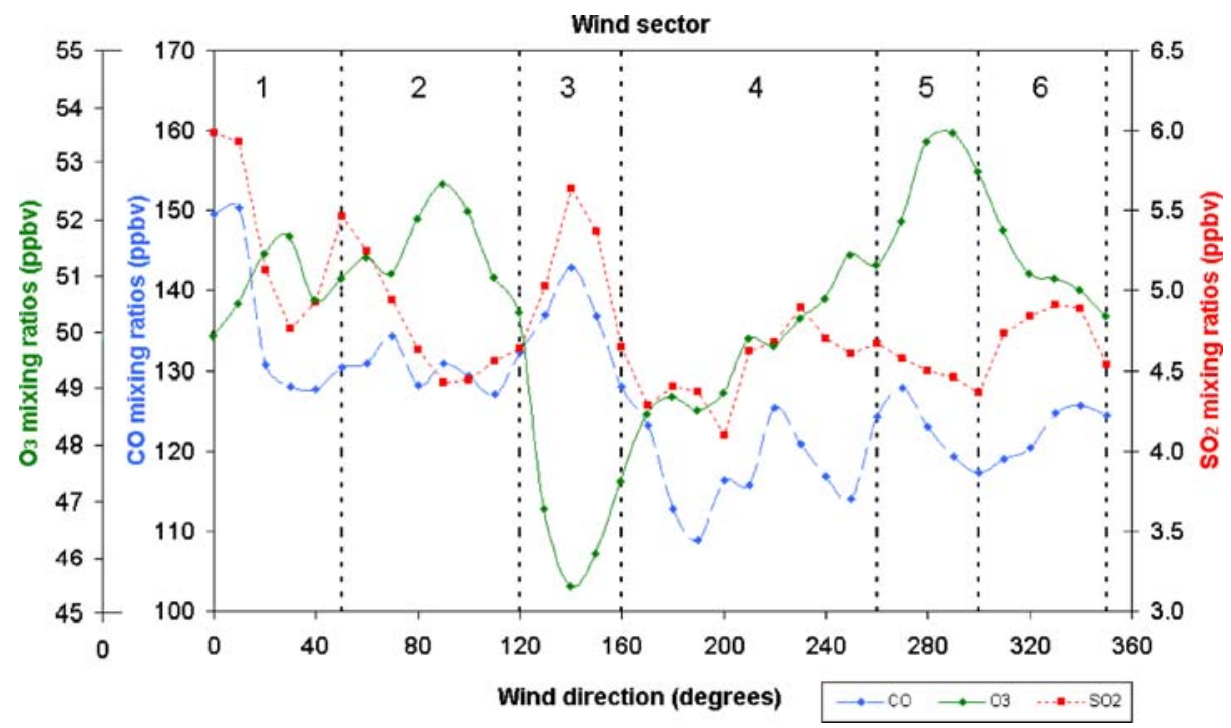

Fig. 4 Variation of Ozone, $\mathrm{CO}$ and $\mathrm{SO}_{2}$ mixing ratios with wind direction on Gozo for the period 2003-2006 
Table 1 Annual mean ozone maxima and minima (ppbv), together with the pollution index, for all years 1997-2006

\begin{tabular}{cccc}
\hline Year & Ozone max & Ozone min & Pollution index \\
\hline 1997 & 57.2 & 41.8 & 1.4 \\
1998 & 57.0 & 41.1 & 1.4 \\
1999 & 57.4 & 42.8 & 1.3 \\
2000 & 58.7 & 44.5 & 1.3 \\
2001 & 59.1 & 45.3 & 1.3 \\
2002 & 57.3 & 43.8 & 1.3 \\
2003 & 65.3 & 48.3 & 1.4 \\
2004 & 59.5 & 44.8 & 1.3 \\
2005 & 57.5 & 43.5 & 1.3 \\
2006 & 56.3 & 42.6 & 1.3 \\
\hline
\end{tabular}

of local origin, but due to transport phenomena in the Central Mediterranean either from the northwest or possibly from recirculation over the densely populated main island of Malta (see Fig. 1). This topic will be further discussed in Section 3.4.

\subsection{Simultaneous surface $\mathrm{CO}$ and $\mathrm{SO}_{2}$ measurements on Gozo}

At Giordan lighthouse, the background CO mixing ratio was measured from 1999 to 2006 and the background $\mathrm{SO}_{2}$ mixing ratio was recorded during the period 2003-2005.

A plot of Ozone, $\mathrm{CO}$ and $\mathrm{SO}_{2}$ mixing ratios versus wind direction is shown in Fig. 4.

Apart from specific anthropogenic events attributed to both recirculation from the main island of Malta (Sector 3 in Fig. 1) as well as emissions from further afield (e.g. Sicilian oil refineries), a clear background variation with the wind sector is found.

In the case of $\mathrm{CO}$ and $\mathrm{SO}_{2}$, they are anti-correlated with ozone. Some of the results have already been discussed by Nolle et al. (2001).

In the case of $\mathrm{SO}_{2}$, maxima not exceeding 6 ppbv are found in the north, northeast (40$80^{\circ}$ ), and southeast $\left(120-160^{\circ}\right)$ and a broader series of peaks between $200^{\circ}$ and $350^{\circ}$.

The $\mathrm{CO}$ and $\mathrm{SO}_{2}$ emissions are probably due to (a) emissions from the Etna to the N/ NE (sector 1 in Fig. 1), (b) Malta to the SE (sector 3), and (c) ship traffic between Gozo and Sicily, as this is the main shipping route to the Middle East (sectors 6 and 2).

It is obvious that the peaks of both $\mathrm{CO}$ and $\mathrm{SO}_{2}$ coincide; this supports the hypothesis that they are due to regional emissions from both the Sicilian mainland as well as ship traffic in the strait of Sicily-Gozo (Löye Pilot et al. 2004).

Due to the low quality of the bunker fuel oil used for the propulsion of seagoing ships, the sulphur content is of the order of 4 wt.\% (Corbett et al. 1999). Thus, the ship plume is a source of $\mathrm{SO}_{2}$ and other primary pollutants $\left(\mathrm{NO}_{\mathrm{x}}\right.$, hydrocarbons, $\mathrm{CO}$, and $\left.\mathrm{CO}_{2}\right)$ as well as aerosol particles (Corbett and Fishbeck 1997). The ship plume can reach several hundred kilometres in length and tens of kilometres in width (Osborne et al. 2001).

Since approximately 25\% (EMEP 1998) of the international seaborne trade volume originates from or is directed to the Mediterranean ports or passes this area towards the Suez canal, the strait between Sicily and the Maltese islands (see Fig. 1) is a major global shipping route and also a source of secondary air pollutants (ozone and other photosmog products) (Lawrence and Crutzen 1999). A recent modelling study indicates that more than $50 \%$ of the sulphate aerosol concentration over the Mediterranean during the summer originates from ship emissions (Marmer and Langmann, 2005). 


\subsection{Long-range transport of air pollutants to the Central Mediterranean}

The entire Mediterranean is strongly affected by long-range transport of air pollutants from Western and Eastern Europe (Lelieveld et al. 2002). Northerly air masses often extend southwards through mountain gaps in the Alps in all seasons (Weather in the Mediterranean 1962). In addition to regional pollution from various sources, pollutants of European origin add to the local burden during their transport to Africa (Kallos et al. 1998). According to the major weather structures in the Mediterranean, the latter is usually divided into three basins (Weather in the Mediterranean 1962; Millan et al. 2002). Gozo, an island of the Maltese archipelago, is centred in the Central Basin. Subordinate to the large-scale meteorology in the Mediterranean, more meso-scale circulations develop in the Central Basin (Kallos et al. 1998). Air masses loaded with pollutants from elsewhere may reach Gozo via the Adriatic and Tyrrhenian seas (Weather in the Mediterranean 1962). Air masses transported to the south have a longer sea track on the way to Gozo and North Africa (Kallos et al. 1998). Due to the long distance over the Mediterranean sea, the relatively cool sea surface in spring and early summer produces conditions of subsidence and stability in the maritime boundary layer for the air parcels mixed in from the lower troposphere. Thus, photochemical ozone production from its precursor pollutants (Güsten 1986) enriches the ozone mixing ratio of these air masses travelling southwards, particularly during the summer months. Since the deposition velocity of ozone over sea water is very small, the air masses loaded with ozone are well preserved during transport. Even in the cooler season, unusually high ozone mixing ratios were measured on Gozo (see Fig. 2a,c).

A typical result of the southward movement of a huge anticyclone loaded with high ozone levels from Western and Central Europe to the Mediterranean is the "August heatwave" of the year 2003 (Black et al. 2004; Fink et al. 2004). Exceptionally long-lasting and spatially extensive episodes of high ozone mixing ratios were measured in Belgium, France, Germany, Switzerland, North and Central Italy during that time (Solberg et al. 2005; Vautard et al. 2005; Cristofanelli et al. 2007). According to our records, the ozone notification threshold of 90 ppbv on Gozo was exceeded frequently in August 2003. The overall average ozone mixing ratio in August 2003 was 4.6 ppbv higher than during all other 9 months of August since 1997 (see Fig. 2c)

As indicated by the air mass back-trajectory and mixing height analysis, these air parcels originated from the European mainland and were circulated into the Central Mediterranean. Four back-trajectories for the August 2003 period are shown in Fig. 5; two of the four events originated in Europe, with the other two being recirculations in the Central Mediterranean.

Depending on the season. the orography of the Central Mediterranean between the flat coast with open desert in the south and topographical features in the north (Sicily, South Italy) as well as the east coast of Tunisia (see Fig. 1) generates regional and local winds with more meso-scale transport characteristics that result in a possible recirculation of loaded air masses in the Central Mediterranean. These regional surface winds in the maritime areas around Italy are called Gregale, Libeccio, and Scirocco (Weather in the Mediterranean 1962). More local winds are sea breezes. The diurnal alteration of land and sea breeze is very pronounced in the Sicilian-Tunisian narrows and on the Libyan coast in the warm and even in the cool season (Lamb 1955); its depth generally extends to heights between 600 and 1,600 $\mathrm{m}$ (Weather in the Mediterranean 1962).

Especially during the summer, strong updrafts over the hot North African desert may cause a much deeper mixing layer with a recirculation of ozone-rich air masses into the lower troposphere. During the evening and the night over the colder Central Mediterranean 
Fig. 5 Four back trajectories for the August 2003 heat wave period

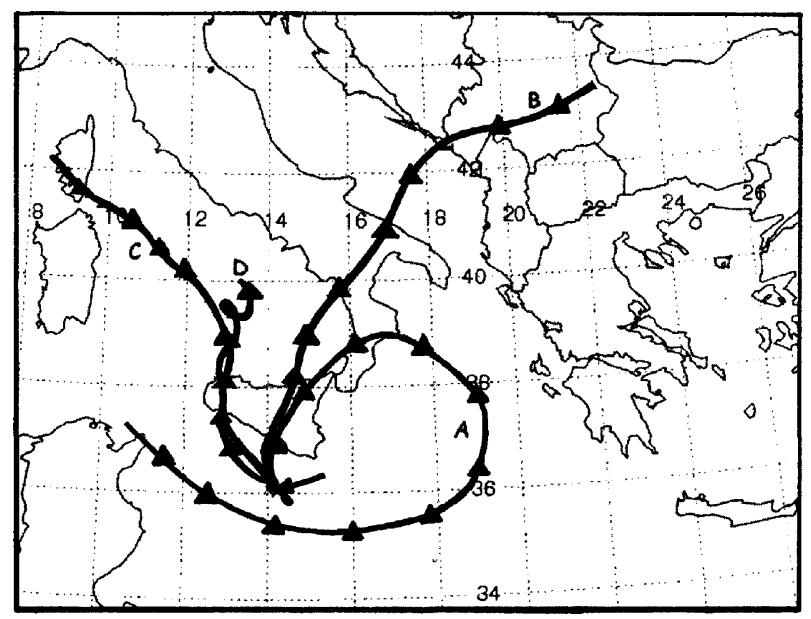

sea, mixing into the shallow maritime boundary layer may occur. This kind of recirculation could explain the high ozone peaks observed in the evening and during the night at the station on Gozo, especially during the night of August 14/15, when the wind came from southerly and south-easterly directions.

North Africa is not generally considered to be a source of tropospheric ozone for Europe (Fischer et al. 2003). There are indications that ozone mixing ratios are low in the North African desert. Deep in the Egyptian desert, the surface ozone mixing ratios change drastically from mean values of $50 \mathrm{ppbv}$ with northerly winds to values of around $30 \mathrm{ppbv}$ when the wind originates from the Libyan desert (Güsten et al. 1996).

More long-term ozone measurements at various locations in southern Italy, on the east coast of Tunisia, and in Libya, combined with meso-scale modelling, will be needed to confirm these conclusions.

\subsection{Regression modelling}

As was described in Section 3.2, the daily $\mathrm{O}_{3}$ max $/ \mathrm{O}_{3}$ min ratio can be used as a pollution indicator of photochemically produced ozone in air. Due to the low index value of $<1.40$, the Gozo station may be considered a good site for measuring background air pollutants (Cvitas and Klasinc 1993; Beck and Grennfelt 1993). For predicting the daily maximum and minimum ozone mixing ratios on the basis of a 10-year data set of ozone measurements, an ANCOVA regression model was used.

Several authors (e.g. US-EPA Report 454, 1999) used regression models to relate ozone mixing ratios to several explanatory variables that may affect and control the ozone levels in a region.

The ANCOVA (Analysis of Covariance) regression model that expresses the ozone mixing ratio as a function of the explanatory variables is EMBED Equation.DSMT4. The response vector $\mathbf{y}$ which includes the ozone mixing ratios is regarded to be random; the design matrix $\mathbf{X}$ contains the non-random observations of the explanatory variables; EMBED Equation.DSMT4 is the vector of unknown regression parameters; EMBED Equation.DSMT4 is the linear component of the model and EMBED Equation.DSMT4 is a vector of error terms, where EMBED Equation.DSMT4 are assumed to be normally distributed. 
The purpose of this study was to fit two ANCOVA regression models using SPSS. These models predict the daily maximum and minimum ozone mixing ratios based on information about relevant predictors. ANCOVA models accommodate both covariates (quantitative predictors) and factors (qualitative predictors) and the design matrix $\mathrm{X}$ includes both covariate values and dummy values representing factor levels. In this study, the covariates are temperature, global radiation, atmospheric pressure, relative humidity, and wind speed. The time of year, wind direction, and time of day are the factors. These factors are respectively categorized into 12 months, six wind sectors, and four time sectors (see Table 2).

The complete data set included hourly measurements of ozone mixing ratios, together with relevant information about the predictors, throughout the period 1997-2005. The daily maximum and minimum ozone mixing ratios were then selected and spurious data points of anomalously high or low ozone readings were excluded from the data set. To determine strong and weak predictors of maximum and minimum ozone mixing ratios (response variables), a stepwise regression procedure was then carried out using the predictors as main effects.

Tests of between-subject effects reveal that the month of year is the best predictor of daily maximum ozone mixing ratios (Table 3). It is followed by the time of day, wind sector, wind speed, relative humidity, and global radiation. This ANCOVA regression model explains $39.6 \%$ of the variation of the maximum ozone mixing ratios. The contributions of temperature and atmospheric pressure in the model fit were not found to be significant. The lack of significance of temperature in the model fit is explained by the fact that the appropriateness of a predictor often depends on what other explanatory variables are with it in the model. An important predictor may be rendered unimportant in the presence of other more significant explanatory variables. Indeed, time of day and month of year considerably account for variations in temperature.

The regression coefficients (parameter estimates) disclose important information about the relationship between the daily maximum ozone mixing ratios and each predictor (Table 4). Maximum ozone mixing ratios are lowest in December, increase abruptly in March, and reach a maximum in May. These ozone mixing ratios are, on the average, retained during the summer and fall rapidly in October. The difference in ozone mixing ratios between May and December is 18.6 ppbv on the average. Wind direction is another important contributor of maximum ozone mixing ratio variation. The maximum ozone mixing ratio is lowest when the wind is blowing from the southeast (wind sector 3). The wind picks up ozone-destroying emissions as it blows over the Maltese Islands. On the average, the maximum ozone mixing ratio increases by 5.4 ppbv when the wind blows from the northwest (wind sector 5). The time sector parameters disclose that the maximum ozone mixing ratio increases by $3.6 \mathrm{ppbv}$ from the morning ozone dip to the afternoon ozone peak on the average. The positive coefficients of relative humidity and global radiation imply that maximum ozone mixing ratios increase with an increase in global radiation and relative humidity. For every 1-unit increment in relative humidity, the maximum ozone mixing ratio is expected to increase by 0.05 ppbv. Similarly, the negative coefficients of wind speed

Table 2 Relation between wind sector/direction and time sector/time of day

\begin{tabular}{|c|c|c|c|c|c|c|}
\hline Wind sector & 1 & 2 & 3 & 4 & 5 & 6 \\
\hline Wind direction & $0-60^{\circ}$ & $60-120^{\circ}$ & $120-170^{\circ}$ & $170-260^{\circ}$ & $260-300^{\circ}$ & $300-360^{\circ}$ \\
\hline Time sector & 1 (Destruction) & \multicolumn{2}{|c|}{2 (Deposition) } & \multicolumn{2}{|c|}{3 (Build-up) } & 4 (Peak) \\
\hline Time of day & 5 P.M. -6 А.M. & \multicolumn{2}{|c|}{6 A.M. -8 A.M. } & \multicolumn{2}{|l|}{8 A.M. -1 P.M. } & 1 P.M. -5 P.M. \\
\hline
\end{tabular}


Table 3 Analysis of variance and goodness of fit for maximum and minimum ozone levels

Tests of between-subjects effects

\begin{tabular}{|c|c|c|c|c|}
\hline \multirow{2}{*}{$\begin{array}{l}\text { Ozone level } \\
\text { Predictor }\end{array}$} & \multicolumn{2}{|l|}{ Maximum } & \multicolumn{2}{|l|}{ Minimum } \\
\hline & $F$-statistic & $P$-value & $F$-statistic & $P$-value \\
\hline Month & 42.65 & 0.000 & 28.82 & 0.000 \\
\hline Time sector & 13.14 & 0.000 & 1.530 & 0.205 \\
\hline Wind sector & 9.153 & 0.000 & 7.836 & 0.000 \\
\hline Relative humidity & 12.06 & 0.001 & 54.36 & 0.000 \\
\hline Global radiation & 4.752 & 0.029 & 19.98 & 0.000 \\
\hline Temperature & 1.119 & 0.290 & 83.87 & 0.000 \\
\hline Pressure & 0.373 & 0.541 & 13.23 & 0.000 \\
\hline Wind speed & 26.38 & 0.000 & 0.019 & 0.890 \\
\hline$R$-squared & 0.396 & & 0.352 & \\
\hline
\end{tabular}

imply that maximum ozone mixing ratios decrease with an increase in wind speed. For every 1-unit increment in wind speed, the maximum ozone mixing ratio is expected to decrease by 0.27 ppbv.

A similar analysis was carried out to relate minimum ozone mixing ratios to relevant explanatory variables (Table 3). Tests of between-subject effects reveal that the month of year is the best predictor of daily minimum ozone mixing ratios. It is followed by temperature, relative humidity, wind sector, global radiation and atmospheric pressure. This ANCOVA regression model explains $35.2 \%$ of the variation of the minimum ozone mixing ratios. The contributions wind speed and time of day were not found to contribute significantly to the variation of minimum ozone levels.

The regression parameters for the month of year reveal appealing results with respect to the daily minimum ozone variation (Table 4). Minimum ozone mixing ratios reach a minimum in December and increase rapidly during the spring period. The minimum ozone mixing ratios retain a high level during the summer period and fall abruptly in October. The difference in the minimum ozone mixing ratios between September and December is $15.9 \mathrm{ppb}$ on the average. Wind direction contributes significantly to the minimum ozone mixing ratio variation. The minimum ozone mixing ratio is lowest when the wind is blowing from the southeast and increases by $4.9 \mathrm{ppbv}$ on the average when the wind blows from the northwest. The analysis also reveals that an increase in temperature, global radiation, and atmospheric pressure and a decrease in relative humidity increase minimum ozone mixing ratios. For every 1 -unit increment in temperature, the minimum ozone mixing ratio is expected to increase by $0.82 \mathrm{ppbv}$. Conversely, for every 1 -unit increment in relative humidity, the minimum ozone mixing ratio is expected to decrease by $0.13 \mathrm{ppbv}$.

Model diagnostics is essential for model validation. Graphical displays of predicted values and residuals can be used to spot oddities and detect outliers and influential data points.

The first scatter plot (Fig. 6a) indicates that the model that fits the maximum ozone data set underestimates very high ozone mixing ratios. The second scatter plot (Fig. 6b) demonstrates that the model that fits the minimum ozone data set underestimates very high ozone mixing ratios and overestimates very low ozone mixing ratios. However, a large proportion of the data points lie very close to the $45^{\circ}$ line, indicating a reasonable small difference between the predicted and actual ozone mixing ratios. 
Table 4 Parameter estimates, standard errors and 95\% confidence limits for maximum and minimum ozone mixing ratios

\begin{tabular}{|c|c|c|c|c|c|c|c|c|}
\hline \multirow{3}{*}{$\begin{array}{l}\text { Ozone level } \\
\text { Model term }\end{array}$} & \multicolumn{4}{|l|}{ Maximum } & \multicolumn{4}{|l|}{ Minimum } \\
\hline & \multirow[t]{2}{*}{$\begin{array}{l}\text { Parameter } \\
\text { estimate }\end{array}$} & \multirow[t]{2}{*}{$\begin{array}{l}\text { Standard } \\
\text { error }\end{array}$} & \multicolumn{2}{|c|}{$\begin{array}{l}95 \% \\
\text { Confidence } \\
\text { limits }\end{array}$} & \multirow[t]{2}{*}{$\begin{array}{l}\text { Parameter } \\
\text { estimate }\end{array}$} & \multirow[t]{2}{*}{$\begin{array}{l}\text { Standard } \\
\text { error }\end{array}$} & \multicolumn{2}{|c|}{$\begin{array}{l}95 \% \\
\text { Confidence } \\
\text { limits }\end{array}$} \\
\hline & & & Lower & Upper & & & Lower & Upper \\
\hline Intercept & 55.91 & 1.662 & 52.6 & 59.2 & -47.66 & 29.48 & -106 & 10.2 \\
\hline [Month = January $]$ & 2.233 & 1.439 & -0.06 & 5.06 & 0.281 & 1.135 & -1.95 & 2.51 \\
\hline [Month = February $]$ & 7.109 & 1.371 & 4.42 & 9.80 & 4.170 & 1.189 & 1.84 & 6.50 \\
\hline [Month = March $]$ & 13.48 & 1.355 & 10.8 & 16.1 & 8.938 & 1.171 & 6.64 & 11.2 \\
\hline [Month = April] & 16.77 & 1.312 & 14.2 & 19.3 & 12.41 & 1.124 & 10.2 & 14.6 \\
\hline [Month = May] & 18.55 & 1.305 & 16.0 & 21.1 & 13.99 & 1.153 & 11.7 & 16.3 \\
\hline [Month = June $]$ & 17.39 & 1.334 & 14.8 & 20.0 & 13.92 & 1.347 & 11.3 & 16.6 \\
\hline$[$ Month = July $]$ & 17.79 & 1.353 & 15.1 & 20.4 & 14.78 & 1.475 & 11.9 & 17.7 \\
\hline [Month = August $]$ & 13.99 & 1.356 & 11.3 & 16.6 & 13.55 & 1.557 & 10.5 & 16.6 \\
\hline$[$ Month $=$ September $]$ & 12.19 & 1.345 & 9.56 & 14.8 & 15.86 & 1.418 & 13.1 & 18.6 \\
\hline [Month = October] & 4.782 & 1.395 & 2.05 & 7.52 & 5.786 & 1.369 & 3.10 & 8.47 \\
\hline$[$ Month $=$ November $]$ & 1.945 & 1.521 & -1.04 & 4.93 & 3.549 & 1.235 & 1.13 & 5.97 \\
\hline [Month = December $]$ & Aliased & & & & Aliased & & & \\
\hline $\begin{array}{l}\text { [Time sector }=\text { ozone } \\
\text { destruction] }\end{array}$ & -0.777 & 0.750 & -2.25 & 0.69 & 1.899 & 1.106 & -0.27 & 4.07 \\
\hline $\begin{array}{l}{[\text { Time sector }=} \\
\text { minimum ozone] }\end{array}$ & -3.561 & 0.580 & -4.70 & -2.42 & 0.355 & 0.943 & -1.50 & 2.21 \\
\hline $\begin{array}{l}\text { [Time sector }=\text { ozone } \\
\text { build-up] }\end{array}$ & -2.930 & 1.387 & -5.65 & -0.21 & 0.254 & 0.731 & -1.18 & 1.69 \\
\hline $\begin{array}{l}{[\text { Time sector }=} \\
\text { maximum ozone] }\end{array}$ & Aliased & & & & Aliased & & & \\
\hline $\begin{array}{l}{[\text { Wind sector }=000-} \\
060]\end{array}$ & -0.842 & 1.292 & -3.38 & 1.69 & -0.113 & 0.643 & -1.38 & 1.15 \\
\hline $\begin{array}{l}{[\text { Wind sector }=060-} \\
120]\end{array}$ & -0.383 & 0.733 & -1.82 & 1.06 & 0.598 & 0.665 & -0.71 & 1.90 \\
\hline $\begin{array}{l}{[\text { Wind sector }=120-} \\
170]\end{array}$ & -4.808 & 1.061 & -6.89 & -2.73 & -3.299 & 0.798 & -4.86 & -1.73 \\
\hline $\begin{array}{l}{[\text { Wind sector }=170-} \\
260]\end{array}$ & -2.541 & 0.689 & -3.89 & -1.19 & -1.414 & 0.949 & -3.28 & 0.45 \\
\hline $\begin{array}{l}{[\text { Wind sector }=260-} \\
300]\end{array}$ & 0.634 & 0.635 & -0.61 & 1.88 & 1.583 & 0.651 & 0.31 & 2.86 \\
\hline $\begin{array}{l}{[\text { Wind sector }=300-} \\
360]\end{array}$ & Aliased & & & & Aliased & & & \\
\hline Relative humidity & 0.046 & 0.015 & 0.02 & 0.08 & -0.125 & 0.016 & -0.16 & -0.09 \\
\hline Global radiation & 0.003 & 0.001 & 0.00 & 0.01 & 0.005 & 0.001 & 0.00 & 0.01 \\
\hline Temperature & -0.106 & 0.100 & -0.30 & 0.09 & 0.824 & 0.090 & 0.65 & 1.00 \\
\hline Atmospheric pressure & -0.023 & 0.038 & -0.09 & 0.05 & 0.107 & 0.029 & 0.05 & 0.17 \\
\hline Wind speed & -0.274 & 0.051 & -0.37 & -0.18 & 0.007 & 0.053 & -0.09 & 0.11 \\
\hline
\end{tabular}

Aliased $=$ Parameter set to zero 

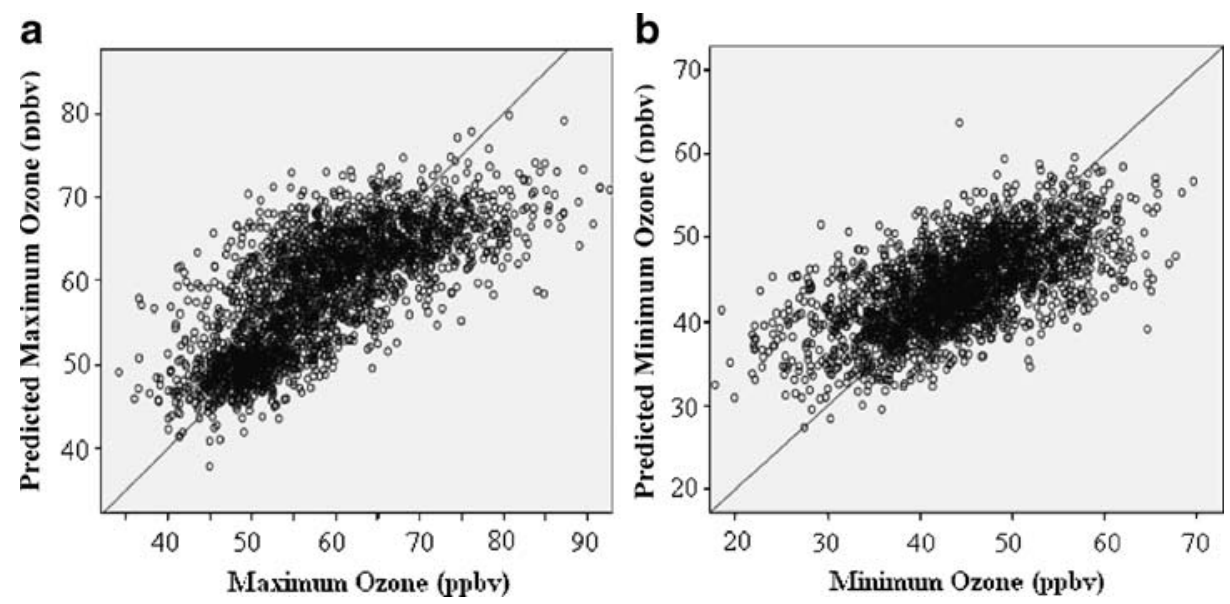

Fig. 6 Model scatter plot for the daily ozone maxima (a) and minima (b) measured on Gozo between 1997 and 2006

In order to assess whether regression assumptions are satisfied, it is important to plot studentized residuals against predicted values. If the errors are normally distributed and the functional form of the model is correct, then about $95 \%$ of the studentized residuals fall between $-2 \%$ and $2.94 .6 \%$ and $93.9 \%$ of the studentized residuals derived from the models fitting the maximum and minimum ozone data sets, respectively, fall between 2 and -2 and this is in agreement with our expectations. These residual plots can also be used to assess misspecifications of the model. If the model is inadequate, the points may display curvilinear or some other systematic pattern which suggests that additional terms should be included in the model. The above scatter plots (Fig. 7a,b) do not display any of these patterns, indicating that the models are adequate.

\subsection{Ozone impact on vegetation on the rural island of Gozo}

As was mentioned in the introduction, ozone is a phytotoxic air pollutant affecting growth and yield of crops. It also has detrimental effects on human health. While the threshold value for the protection of human health of $120 \mu \mathrm{g} \mathrm{m}^{-3}(\sim 60 \mathrm{ppbv})$ for an $8-\mathrm{h}$ average ozone concentration was fixed by the EU (EU Directive 2002/3), the scientific community proposed a so-called AOT40 value (Accumulated hourly ozone concentration Over a Threshold) for crops and trees of $40 \mathrm{ppbv}$ for the European Union (Ashmore et al. 2004). Both threshold values are based on a cumulative exposure index using different cut-off concentrations. The lower index value for plants indicates that plants may be more vulnerable to ozone than human beings. The pros and cons of the AOT40 were discussed in detail (De Santis 1999, 2000; Ashmore and Fuhrer 2000; Ashmore et al. 2004).

A central aspect is whether a European vegetation standard is fair to all European countries, especially in the Mediterranean (De Santis 1999).

In the light of the high average ozone mixing ratio on Gozo, this may be questioned. As indicated in Table 5, the average monthly mean AOT40 value exceeded the threshold for all months during the last 10 years, except for the winter (December till March) (Nolle et al. 2002). As regards the recommended threshold of 3,000 ppbv'h (Ashmore and Fuhrer 2000) the total number of hours (see Table 5) violating the AOT40 limit varies from 2,190 $\mathrm{h}$ in December to 3,554 h in October. During the growing season on Gozo (April to August), the 

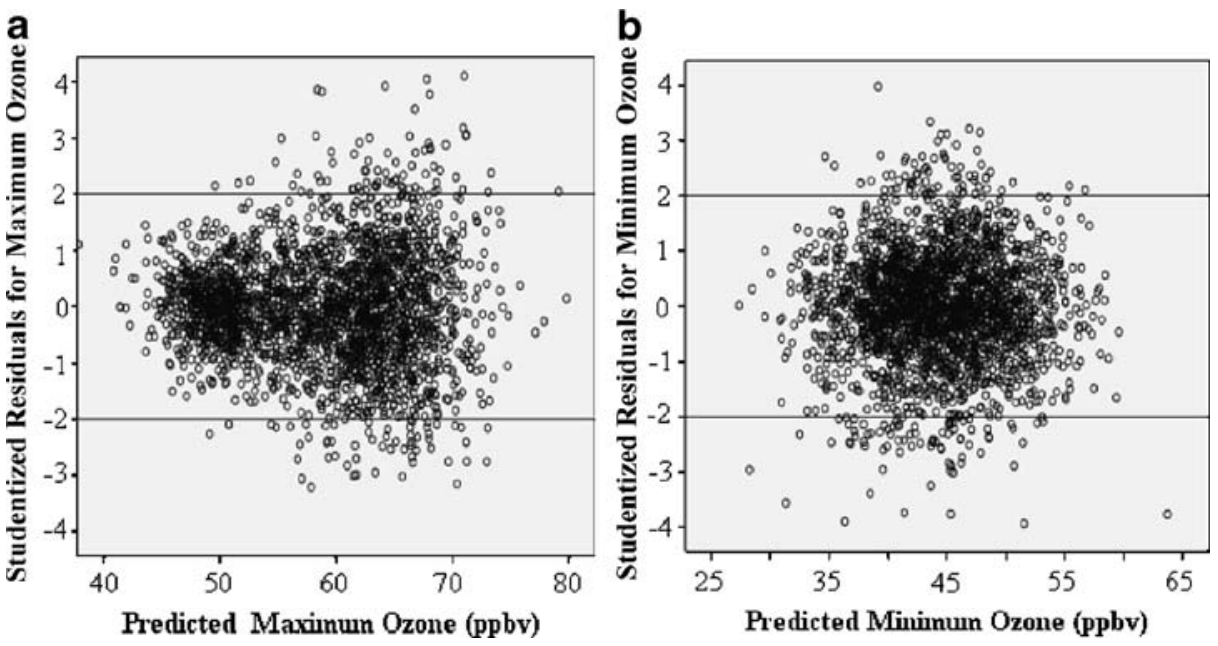

Fig. 7 Plot of Studentized residuals against predicted values for maximum ozone (a) and minimum ozone (b)

monthly mean AOT40 values range from 4,668 ppbv'h for April to 5,991 ppbv'h for August. During June, the monthly mean AOT40 value is more than twice the allowed threshold value of 3,000 ppbv h. Thus, the rural island of Gozo which is the main agricultural provider of vegetables and fruit for the state of Malta probably encounters severe horticultural crop losses of high economic value.

\section{Summary and conclusion}

A 10-year series of ozone mixing ratios measured between 1997 and 2006 on the island of Gozo was studied and a high annual mean value of $50.2 \mathrm{ppbv}$ was found. This is the highest average annual background ozone mixing ratio ever measured in Europe. The constantly high annual average ozone mixing ratio on Gozo is in contrast to the Eastern Mediterranean, where the trend shows a decrease in the ozone mixing ratio over the same period. We attribute the high ozone mixing ratio on Gozo to (a) long-range transport of polluted air masses from Europe by northerly winds as well as to (b) higher regional pollution by ship traffic and emissions from the Sicilian mainland.

Despite the high annual mean value for ozone, the low index value for ozone pollution identifies Gozo to be a good measuring site for background air.

Table 5 Monthly average of the daily (8 A.M.-8 P.M.) AOT40 (ppbv h) values and total number of hours of AOT40 violations for the period 1997-2006

\begin{tabular}{lllllllllllll}
\hline & Jan & Feb & Mar & Apr & May & Jun & Jul & Aug & Sep & Oct & Nov & Dec \\
\hline $\begin{array}{l}\text { Mean AOT40 } \\
\text { (ppbv h) }\end{array}$ & 2,023 & 3,386 & 4,668 & 6,409 & 7,458 & 6,166 & 5,991 & 4,912 & 4,814 & 2,513 & 1,655 & 1,608 \\
Total hours & 2,765 & 2,834 & 3,122 & 3,516 & 3,911 & 3,529 & 3,554 & 3,234 & 3,112 & 2,446 & 2,194 & 2,190 \\
\hline
\end{tabular}


By fitting a statistical model for the 10 years of ozone observations, daily maximum and minimum ozone mixing ratios can be predicted for the Central Mediterranean based on Gozo. This model will be used by our meteorological office to predict these values on a daily basis.

From March to November, the AOT40 threshold value of $3,000 \mathrm{ppbv} h$ for the protection of crops is constantly exceeded on Gozo. The extremely high ambient ozone mixing ratios on Gozo are presumably responsible for crop losses of high economic value.

Acknowledgements We wish to thank Mr Saviour Porter from the Malta Meteorological Office, Malta International Airport as well as Mr Charles Yousif and Mr Mario Fsadni from the Institute of Energy Technology of the University of Malta for supplying the pressure and radiation measurements missing in our own data set.

\section{References}

Altshuller, A.P., Bufalini, J.J.: Photochemical aspects of air pollution: a review. Environ. Sci. Technol. 5, 3964 (1972). doi:10.1021/es60048a001

Ashmore, M., Fuhrer, J.: New directions: use and abuse of the AOT40 concept. Atmos. Environ. 34, 11571159 (2000). doi:10.1016/S1352-2310(99)00529-4

Ashmore, M., Emberson, L., Karlsson, P.E., Pleijel, H.: New directions: a new generation of ozone critical levels for the protection of vegetation in Europe. Atmos. Environ. 38, 2213-2214 (2004). doi:10.1016/j. atmosenv.2004.02.029

Black, E., Blackburn, M., Harrison, G., Hoskins, B., Methven, J.: Factors contributing to the summer 2003 European heatwave. Weather 59(8), 217-223 (2004)

Beck, J., Grennfelt, P.: Distribution of ozone over Europe. In: Borrell, P.M., Borrell, P., Cvitas, T., Seiler, W. (ed.) Proc. EUROTRAC Symp. 1992, pp. 43-58. SPB Academic, The Hague, The Netherlands (1993)

Chetcuti, D., Buhagiar, A., Schembri, P.J., Ventura, F.: The climate of the Maltese Islands-a review, pp. 3033. Malta University Press, Msida (1992)

Corbett, J.J., Fishbeck, P.S., Pandis, S.N.: Global nitrogen and sulphur inventories for oceangoing ships. J. Geophys. Res. 104, 3457-3470 (1999). doi:10.1029/1998JD100040

Corbett, J.J., Fishbeck, P.S.: Emissions from ships. Science 298, 823-824 (1997). doi:10.1126/ science.278.5339.823

Cristofanelli, P., Bonasoni, P., Carboni, G., Calzolari, F., Casarola, L., Zauli Sajani, S., et al.: Anomalous high ozone concentrations recorded at a high mountain station in Italy in summer 2003. Atmos. Environ. 41, 1383-1394 (2007). doi:10.1016/j.atmosenv.2006.10.017

Cvitas, T., Klasinc, L.: Measurement of tropospheric ozone in the Eastern Mediterranean. Boll. Geofisico 16, 521-527 (1993)

Cvitas, T., Kezele, N., Klasinc, L., Lisac, J.: Tropospheric ozone measurements in Croatia. Pure Appl. Chem. 67, 1450-1453 (1995)

Cvitas, T., Kezele, N., Klasinc, L.: Boundary layer ozone in Croatia. J. Atmos. Chem. 28, 125-134 (1997). doi:10.1023/A:1005845232426

De Santis, F.: New directions: will a new European vegetation ozone standard be fair to all European countries? Atmos. Environ. 33, 3873-3874 (1999). doi:10.1016/S1352-2310(99)00110-7

De Santis, F.: Reply to "Use and abuse of the AOT40 concept" by M. Ashmore and J. Fuhrer. Atmos. Environ. 34, 1158-1159 (2000). doi:10.1016/S1352-2310(99)00530-0

Dickerson, R.R., Delany, A.C.: Modification of a commercial gas filter Correlation CO Detector for enhanced sensitivity. J. Atmos. Ocean. Technol. 5, 424-431 (1988). doi:10.1175/1520-0426(1988) 005<0424:MOACGF>2.0.CO;2

European Monitoring and Evaluation Programme (EMEP): Transboundary photooxidant air pollution in Europe: calculations of tropospheric ozone and comparison with observations, Report EMEP Meteorological Synthesizing Centre-West. NILU, Norway (1998), July

EU Directive 2002/3 of the European Parliament and of the Council (11 Febr. 2002) relating to ozone in ambient air. Official Journal of the European Communities, Annex 1, 9th March 2002 
Fink, A.H., Brucher, T., Kruger, A., Leckebush, G.C., Pinto, J.G., Ulbrich, U.: The 2003 European summer heatwave and drought - synoptic diagnosis and impacts. Weather 59(8), 209-215 (2004)

Fischer, H., Kormann, R., Klüpfel, T., Gurk, C., Königstedt, R., Parchatka, U., Mühle, J., Rhee, T.S., Brenninkmeijer, C.A.M., Bonasoni, P., Sohl, A.: Ozone production and trace gas correlations during the June 2000 MINATROC intensive measurement campaign at Mt. Cimone. Atmos. Chem. Phys. 3, 725$738(2003)$

Gerasopoulos, E., Kouvarakis, G., Vrekoussis, M., Kanakidou, M., Mihalopoulos, N.: Ozone variability in the marine boundary layer of the Eastern Mediterranean based on 7-year observations. J. Geophys. Res. 110(No. D15), D15309 (2005). doi:10.1029/2005JD005991

Güsten, H.: Formation, transport, and control of photochemical smog. In: Hutzinger, O. (ed.) The Handbook of Environmental Chemistry, Vol 4/ Part A-Air Pollution, pp. 53-106. Springer, Berlin, Germany (1986)

Güsten, H., Heinrich, G., Mönnich, E., Sprung, D., Ramadan, A.B., EzzEl-Din, M.R.M., Ahmed, D.M., Hassan, G.K.Y.: On-line measurements of ozone surface fluxes. Part II: Surface-level ozone fluxes onto the Sahara desert. Atmos. Environ. 30, 911-918 (1996)

HYSPLIT 4 (HYbrid Single-Particle Lagrangian Integrated Trajectory) Model 1997. Web address: http:// www.arl.noaa.gov./ready/hysplit4.html, NOAA Air Resources Laboratory, Silver Spring, MD, USA

Jonson, J.E., Simpson, D., Fagerli, H., Solberg, S.: Can we explain the trends in European ozone levels? Atmos. Chem. Phys. 6, 51-66 (2006)

Kallos, G., Kotroni, V., Lagouvardos, K., Papadopoulos, A.: On the long-range transport of air pollutants from Europe to Africa. Geophys. Res. Lett. 25, 619-622 (1998)

Kouvarakis, G., Tsigardis, K., Kanakidou, M., Mihalopoulos, N.: Temporal variations of surface regional background ozone over Crete island in the southeast Mediterranean. J. Geophys. Res. 105(No. D4), 4399-4407 (2000)

Kouvarakis, G., Vrekoussis, M., Mihalopoulos, N., Kourtidis, K., Rappenglueck, B., Gerasopoulos, E., Zerefos, C.: Spatial and temporal variability of tropospheric ozone in the boundary layer above the Aegean Sea (Eastern Mediterranean). J. Geophys. Res. 107(No. D18), 8137 (2002). doi:10.1029/ 2000JD000081

Lamb, H.H.: Malta's sea breezes. Weather 10, 256-264 (1955)

Lawrence, M.G., Crutzen, P.J.: Influence of $\mathrm{NO}_{\mathrm{x}}$ emissions from ships on tropospheric photochemistry and climate. Nature 402, 167-170 (1999)

Lelieveld, J., and 30 co-authors: Global air pollution crossroads over the Mediterranean. Science 298, 794799 (2002)

Löye Pilot, M.D., Mihalopoulos, N., Kouvarakis, G., Markaki, Z., Oikonomou, C., Nolle, M., Ellul, R.: Oneyear data set of atmospheric deposition of Saharan dust and nutrients at Malta. ADIOS Report to European Commission. Deliverable No. 44. February (2004)

Marmer, E., Langmann, B.: Impact of ship emissions on the Mediterranean summertime pollution and climate: a regional model study. Atmos. Environ. 39, 4659-4669 (2005)

Millan, M.M., Sanz, M.J., Salvador, R., Mantilla, E.: Atmospheric dynamics and ozone cycles related to nitrogen deposition in the western Mediterranean. Environ. Pollut. 118, 167-186 (2002)

Monks, P.S.: A review of the observations and origins of the spring ozone maximum. Atmos. Environ. 34, 3545-3561 (2000)

Nakicenovic, N.: IPCC Special Report on Emission Scenarios. A special report of working group III of the Intergovernmental Panel on Climate Change, p. 599. Cambridge University Press, Cambridge, UK $(2000)$

Nolle, M., Ellul, R., Güsten, H., Heinrich, G.: Long term background ozone and carbon monoxide measurements on the Maltese Islands. Proceedings of 8th European Symposium on the Physico Chemical Behaviour of Atmospheric Pollutants. September 2001, Turin, Italy (2001)

Nolle, M., Ellul, R., Heinrich, G., Güsten, H.: A long term study of background ozone concentrations in the Central Mediterranean-diurnal and seasonal variations on the island of Gozo. Atmos. Environ. 36, 1391-1402 (2002)

Nolle, M., Ellul, R., Ventura, F., Güsten, H.: A study of historical surface ozone measurements (1884-1900) on the island of Gozo in the central Mediterranean. Atmos. Environ. 39, 5608-5618 (2005)

Osborne, S.R., Johnson, D.W., Bauer, K.N., Wood, R.: Modification of the aerosol size distribution within exhaust plumes produced by diesel powered ships. J. Geophys. Res. 106(D9), 9827-9842 (2001)

Scheel, H.E., Aresbough, H., Geiss, H., Gormiscek, B., Granby, K., Haszpra, L., Klasinc, L., Kley, D., Laurila, T., Lindskog, A., Roemer, M., Schmitt, R., Simmond, P., Solberg, S., Toupande, G.: On the spatial distribution and seasonal variation of lower tropospheric ozone over Europe. J. Atmos. Chem. 28, 11-28 (1997) 
Solberg, S., Coddeville, P., Forster, C., Hov, Ø., Orsolini, Y., Uhse, K.: European surface ozone in the extreme summer 2003. Atmos. Chem. Phys. Discuss. 5, 9003-9038 (2005)

United States Environmental Protection Agency Report No. 454/R-99-009, July 1999, Guideline for developing an ozone forecasting program. Research Triangle Park, NC 27711, USA

Vingarzan, R.: A review of surface ozone background levels and trends. Atmos. Environ. 38, 3431-3442 (2004)

Vautard, R., Honore, C., Beekman, M., Rouil, L.: Simulation of ozone during the August 2003 heat wave and emission control scenarios. Atmos. Environ. 39, 2957-2967 (2005)

Weather in the Mediterranean: Vol 1 (2nd Edition), General Meteorology, Air Ministry, Meteorological Office, H.M.S.O. Code No. 40-142-1-62, UK (1962)

WHO (World Health Organization) Report: Air Quality Guidelines for Europe. WHO Regional Publications, European Series No. 23; World Health Organization, Copenhagen (1987) 